\title{
Sodium Ferrite/Carbon Dioxide Reactivity for High Temperature Thermochemical Energy Storage
}

\author{
Hiroki TAKASU, ${ }^{*}$ Hitoshi HOSHINO, Yoshiro TAMURA, Seon Tae KIM and Yukitaka KATO \\ Laboratory for Advanced Nuclear Energy, Institute of Innovative Research, Tokyo Institute of Technology, 2-12-1-N1-22, \\ O-okayama, Meguro-ku, Tokyo, 152-8550 Japan.
}

(Received on March 16, 2018; accepted on September 21, 2018)

\begin{abstract}
The reaction of sodium ferrite $\left(\mathrm{NaFeO}_{2}\right)$ with carbon dioxide shows great promise for use in new high temperature thermochemical energy storage (TcES) systems. Therefore, the chemical reaction between $\mathrm{NaFeO}_{2}$ and $\mathrm{CO}_{2}$ was investigated via thermogravimetric experiments. Analysis of $\mathrm{x}$-ray diffraction patterns confirmed that a mixture of $\mathrm{Na}_{2} \mathrm{CO}_{3}$ and $\mathrm{Fe}_{2} \mathrm{O}_{3}$ was completely converted to $\mathrm{NaFeO}_{2}$ after heating at $900^{\circ} \mathrm{C}$. Under a $\mathrm{CO}_{2}$ pressure of $100 \mathrm{kPa}$, decarbonation and carbonation of the sample proceeded at temperatures over $850^{\circ} \mathrm{C}$ and under $750^{\circ} \mathrm{C}$, respectively. The starting temperatures of decarbonation and carbonation decreased with decreasing $\mathrm{CO}_{2}$ pressure. A cyclic experiment was conducted using the pressure swing absorption method at temperatures of $700-900^{\circ} \mathrm{C}$. The change in reacted mole fraction kept increasing gradually after the second cycle, and it reached 0.835 during the 15 th cycle. According to surface observations, a porous structure formed after the 15th cycle. This improved $\mathrm{CO}_{2}$ diffusivity through the sample and it appears to be the cause of the enhanced reactivity observed during the cyclic experiment with increasing cycle number. The volumetric and the gravimetric thermal energy densities of $\mathrm{NaFeO}_{2}$ were estimated as $760 \mathrm{~kJ} \mathrm{~L}^{-1}$ and $450 \mathrm{~kJ} \mathrm{~kg}^{-1}$, respectively. These results indicate that $\mathrm{NaFeO}_{2}$ has potential to be used as a TcES material at temperatures around $700-900^{\circ} \mathrm{C}$ for utilization of surplus heat in iron-making and other high-temperature processes.
\end{abstract}

KEY WORDS: thermochemical energy storage; sodium ferrite; carbon dioxide.

\section{Introduction}

Owing to the mass consumption of energy in the last few decades, ${ }^{1)}$ the depletion of fossil fuel sources is anticipated. Therefore, the development and introduction of technologies for improving fossil fuel extraction or renewable energy usage have become extremely important research goals.

According to recent studies of energy consumption in Japan, ${ }^{2)}$ over $44 \%$ of the energy produced in 2014 was consumed by industry. In particular, the iron and steel industry is one of the most energy intensive sectors and accounted for $32 \%$ of industrial energy consumption. Even in countries that are members of the Organization for Economic Co-operation and Development, the iron and steel industry accounted for $10 \%$ of total energy consumption in the industrial sector in 2012. ${ }^{3)}$ The quantity of waste heat generated by the iron and steel industry is quite large in China, and $46 \%$ of the non-recycled heat represented high temperature thermal energy over $500^{\circ} \mathrm{C}$.

Because of this situation, various studies have been conducted to find ways to utilize such waste heat in the iron and steel industry. ${ }^{5-8)}$ Particularly, a suitable thermal energy storage system is essential for an efficient waste heat recovery system, and research into sensible and latent heat storage

\footnotetext{
* Corresponding author: E-mail: takasu.h.aa@m.titech.ac.jp DOI: https://doi.org/10.2355/isijinternational.ISIJINT-2018-182
}

has been reported. ${ }^{5,6,9,10)}$ Myagmarjav et al. ${ }^{11)}$ proposed a magnesium oxide/water system as a thermochemical energy storage (TcES) system to recover waste heat at a temperature range of $200-300^{\circ} \mathrm{C}$. Their system had the advantages such as lower energy loss during long-term storage, a high thermal storage density, and a constant temperature output owing to chemical equilibrium. It showed good energy density and demonstrated the potential of TcES systems for applications in the iron and steel industry. Therefore, it can also be expected that TcES systems will be applied for high temperature thermal energy storage in the iron and steel industry. However, so far, only a few carbonation reactions of metallic oxides, such as calcium oxide and lead oxide, have been studied for use in relatively high-temperature TcES systems, ${ }^{12-14)}$ and they have problems with cyclic durability.

In our past reports, ${ }^{15,16}$ the lithium orthosilicate $\left(\mathrm{Li}_{4} \mathrm{SiO}_{4}\right) /$ carbon dioxide $\left(\mathrm{CO}_{2}\right)$ system was proposed as a high temperature $\left(700^{\circ} \mathrm{C}\right) \mathrm{TcES}$ system, and it showed good cyclic durability and potential as a high temperature TcES material. At first, $\mathrm{Li}_{4} \mathrm{SiO}_{4}$ was developed as a $\mathrm{CO}_{2}$ separator by Nakagawa and Ohashi. ${ }^{17)}$ An interesting characteristic is that the reaction temperature between a metallic oxide and $\mathrm{CO}_{2}$ decreases when the metallic oxide forms a composite oxide with some other material such as $\mathrm{Li}_{2} \mathrm{SiO}_{3}$ or $\mathrm{ZrO}_{2} .{ }^{17,18)}$ This can be explained by the Gibbs free energy of reaction, $\Delta G$ $\left[\mathrm{kJ} \mathrm{mol}^{-1}\right]$, as shown in Fig. 1. ${ }^{19,20)}$ 
Temperatures at $\Delta G=0$ are equilibrium reaction temperatures at standard pressure, and decarbonation is thermodynamically favorable above this temperature. The equilibrium temperatures of Eqs. (1) and (2) are $1600^{\circ} \mathrm{C}$ and $710^{\circ} \mathrm{C}$, respectively, as seen in Fig. 1 and Table 1.

$$
\begin{aligned}
& \mathrm{Li}_{2} \mathrm{O}+\mathrm{CO}_{2} \rightleftarrows \mathrm{Li}_{2} \mathrm{CO}_{3}, \Delta H_{\mathrm{r}, 700^{\circ} \mathrm{C}}=-206 \mathrm{~kJ} \mathrm{~mol}^{-1} \ldots \ldots . . \\
& \mathrm{Li}_{4} \mathrm{SiO}_{4}+\mathrm{CO}_{2} \rightleftarrows \mathrm{Li}_{2} \mathrm{CO}_{3}+\mathrm{Li}_{2} \mathrm{SiO}_{3}, \\
& \Delta H_{\mathrm{r}, 700^{\circ} \mathrm{C}}=-103 \mathrm{~kJ} \mathrm{~mol}^{-1}
\end{aligned}
$$

This implies that several series of oxide composites can be developed by changing the combination of a metallic oxide and other appropriate materials, and they have potential to be used in TcES systems.

In order to find a new series of composite oxides, we focused on the sodium ferrite $\left(\mathrm{NaFeO}_{2}\right) / \mathrm{CO}_{2}$ reaction in this report. $\mathrm{NaFeO}_{2}$ is a composite oxide of sodium oxide $\left(\mathrm{Na}_{2} \mathrm{O}\right)$ and iron oxide $\left(\mathrm{Fe}_{2} \mathrm{O}_{3}\right)$, and the reaction formulas are described in Eqs. (3) and (4).

$$
\begin{aligned}
\mathrm{Na}_{2} \mathrm{O}+\mathrm{CO}_{2} \rightleftarrows \mathrm{Na}_{2} \mathrm{CO}_{3}, \quad \Delta H_{\mathrm{r}, 700^{\circ} \mathrm{C}}=-308 \mathrm{~kJ} \mathrm{~mol}^{-1} \ldots . .(3) \\
2 \mathrm{NaFeO}_{2}+\mathrm{CO}_{2} \rightleftarrows \mathrm{Na}_{2} \mathrm{CO}_{3}+\mathrm{Fe}_{2} \mathrm{O}_{3}, \\
\Delta H_{\mathrm{r}, 700^{\circ} \mathrm{C}}=-119 \mathrm{~kJ} \mathrm{~mol}^{-1}
\end{aligned}
$$

According to thermodynamic calculations as shown in Fig. 1, the equilibrium temperature moves from $2100^{\circ} \mathrm{C}$ to $1000^{\circ} \mathrm{C}$ owing to the addition of $\mathrm{Fe}_{2} \mathrm{O}_{3}$. In addition, $\mathrm{NaFeO}_{2}$ has an attractive price compared with other composite oxides. ${ }^{21)}$ Therefore, the $\mathrm{NaFeO} / \mathrm{CO}_{2}$ reaction is expected to be useful as a TcES system at high temperatures. However, few reports of this reaction have been published ${ }^{22,23)}$ to date,

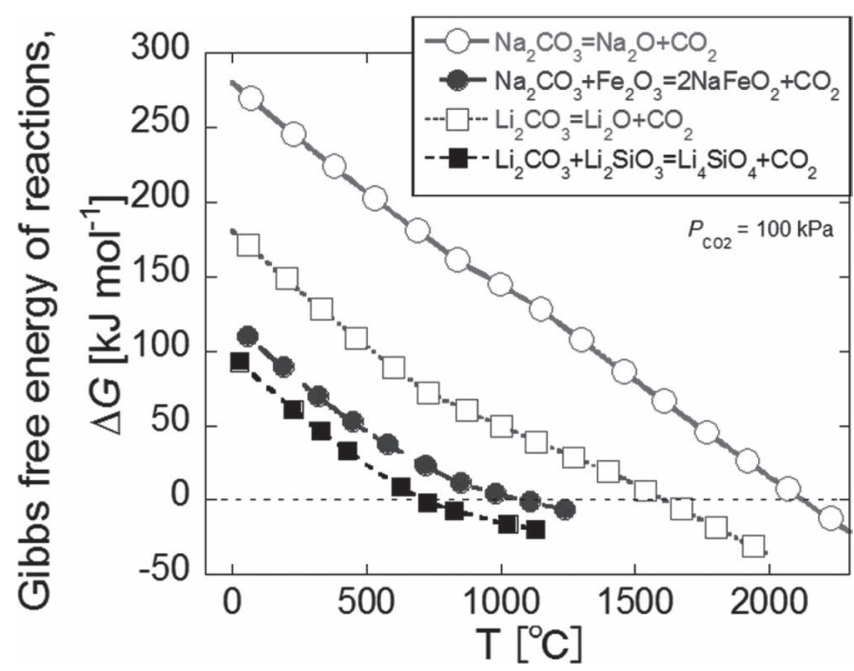

Fig. 1. Gibbs free energy changes of metallic oxide/ $\mathrm{CO}_{2}$ reaction systems.

Table 1. Summary of equilibrium reaction temperatures at standard pressure of metallic oxide $/ \mathrm{CO}_{2}$ reaction systems.

$$
\text { Eq. (1) Eq. (2) Eq. (3) Eq. (4) }
$$

$\begin{gathered}\text { Equilibrium reaction temperatures } \\ \text { at standard pressure }\end{gathered}$
$19,20)$$\quad 1600^{\circ} \mathrm{C} \quad 710^{\circ} \mathrm{C} \quad 2100^{\circ} \mathrm{C} \quad 1100^{\circ} \mathrm{C}$ and further investigation is required.

In order to develop $\mathrm{NaFeO}_{2}$ as a TcES material at high temperatures, the reactivity of a sample at high temperature was measured through thermogravimetric experiments, and its cyclic durability was also investigated. In order to approximate a real TcES system, all experiments were conducted under a $100 \mathrm{vol} \% \mathrm{CO}_{2}$ atmosphere in a closed reactor.

\section{Experimental}

\subsection{Sample Preparation}

Sodium carbonate $\left(\mathrm{Na}_{2} \mathrm{CO}_{3}, 99.98 \%\right.$, Wako Pure Chemical Industries Ltd., melting point: $851^{\circ} \mathrm{C}$ ) and iron oxide $\left(\mathrm{Fe}_{2} \mathrm{O}_{3}\right.$, min. 95.0\%, Wako Pure Chemical Industries Ltd., melting point: $1565^{\circ} \mathrm{C}$ ) were mixed using a mortar and pestle, and then samples were prepared. The molar mixing ratio of $\mathrm{Na}_{2} \mathrm{CO}_{3} / \mathrm{Fe}_{2} \mathrm{O}_{3}$ was $1: 1$.

\subsection{Thermogravimetric Experiments}

All experiments were conducted using a thermobalance (TG-9600S; Ulvac Shinku-Riko Inc.) in a closed system under a $100 \mathrm{vol} \% \mathrm{CO}_{2}$ atmosphere.

Thermal decomposition experiments were conducted with $\mathrm{Na}_{2} \mathrm{CO}_{3}+\mathrm{Fe}_{2} \mathrm{O}_{3}$ samples. The temperature was increased from room temperature to $900^{\circ} \mathrm{C}$ at a constant heating rate of $5^{\circ} \mathrm{C} \mathrm{min}{ }^{-1}$ and kept at $900^{\circ} \mathrm{C}$ for $30 \mathrm{~min}$. The $\mathrm{CO}_{2}$ pressure was $100 \mathrm{kPa}$.

In order to investigate the temperature and pressure dependence of the sample reactivity, thermogravimetric experiments were conducted with $\mathrm{Na}_{2} \mathrm{CO}_{3}+\mathrm{Fe}_{2} \mathrm{O}_{3}$ samples between 100 and $900^{\circ} \mathrm{C}$ under various $\mathrm{CO}_{2}$ pressures (20, 40, 60, 80, and $100 \mathrm{kPa}$ ). Samples of $\mathrm{Na}_{2} \mathrm{CO}_{3}+\mathrm{Fe}_{2} \mathrm{O}_{3}$ were heated to remove water at $100^{\circ} \mathrm{C}$ in advance, and then the $\mathrm{CO}_{2}$ pressure was controlled at the target values. Subsequently, the temperature was increased to $900^{\circ} \mathrm{C}$ at a constant heating rate of $5^{\circ} \mathrm{C} \mathrm{min}^{-1}$. After reaching $900^{\circ} \mathrm{C}$, the temperature was decreased to $100^{\circ} \mathrm{C}$ at a constant cooling rate of $5^{\circ} \mathrm{C} \min ^{-1}$.

The reacted mole fraction, $x$, was calculated from the mass change of the sample measured by the balance and defined in Eq. (5).

$$
x=1+\frac{\Delta m / M_{\mathrm{CO}_{2}}}{m_{0} /\left(M_{\mathrm{Na}_{2} \mathrm{CO}_{3}}+M_{\mathrm{Fe}_{2} \mathrm{O}_{3}}\right)}
$$

$\Delta m[\mathrm{~g}], M_{\mathrm{CO}_{2}}, M_{\mathrm{Na}_{2} \mathrm{CO}_{3}}, M_{\mathrm{Fe}_{2} \mathrm{O}_{3}}\left[\mathrm{~g} \mathrm{~mol}^{-1}\right]$, and $m_{0}[\mathrm{~g}]$ indicate the mass change of the sample, molecular weights of $\mathrm{CO}_{2}$, $\mathrm{Na}_{2} \mathrm{CO}_{3}$ and $\mathrm{Fe}_{2} \mathrm{O}_{3}$, and the initial mass of $\mathrm{Na}_{2} \mathrm{CO}_{3}+\mathrm{Fe}_{2} \mathrm{O}_{3}$, respectively.

\subsection{Cyclic Experiments}

Cyclic experiments were conducted with $\mathrm{NaFeO}_{2}$ samples using a temperature swing absorption (TS) method under $100 \mathrm{kPa}$ of $\mathrm{CO}_{2}$ pressure. Initially, $\mathrm{Na}_{2} \mathrm{CO}_{3}+\mathrm{Fe}_{2} \mathrm{O}_{3}$ samples were heated to remove water at $100^{\circ} \mathrm{C}$, and then the $\mathrm{CO}_{2}$ pressure was held at $100 \mathrm{kPa}$. Subsequently, the temperature was increased to $900^{\circ} \mathrm{C}$ at a constant heating rate of $5^{\circ} \mathrm{C} \mathrm{min}^{-1}$. After that, the temperature varied alternately from $700^{\circ} \mathrm{C}$ for $1 \mathrm{~h}$ as the carbonation process to $900^{\circ} \mathrm{C}$ for $30 \mathrm{~min}$ as the decarbonation process. 
The changes in reacted mole fraction during the carbonation and decarbonation processes, $\Delta x_{\text {carb }}$ and $\Delta x_{\text {deca }}$, are expressed by Eqs. (6) and (7), and described in Fig. 2.

$$
\begin{aligned}
& \Delta x_{\text {carb }}=x_{\text {carb }, \mathrm{f}}-x_{\text {carb }, \mathrm{i}} \\
& \Delta x_{\text {deca }}=x_{\text {carb }, \mathrm{i}}-x_{\text {carb }, \mathrm{f}}
\end{aligned}
$$

$x_{\text {carb,i, }}, x_{\text {deca,i, }}, x_{\text {carb,f }}$ and $x_{\text {deca, }}$ refer to values of $x$ at the beginning and the end of the carbonation and decarbonation processes in each cycle during the cyclic experiment.

\subsection{Characterization}

After a $\mathrm{Na}_{2} \mathrm{CO}_{3}+\mathrm{Fe}_{2} \mathrm{O}_{3}$ sample was heated at $900^{\circ} \mathrm{C}$ for $30 \mathrm{~min}$, the sample was characterized by X-ray diffraction (XRD, MiniFlex600, Rigaku).

$\mathrm{NaFeO}_{2}$ samples after the 1st and 15 th cycles during the cyclic experiment were characterized by scanning electron microscopy (SEM, SM-200, Topcon Corp.).

\section{Results and Discussion}

Figure 3 shows the results of the thermal decomposition of a $\mathrm{Na}_{2} \mathrm{CO}_{3}+\mathrm{Fe}_{2} \mathrm{O}_{3}$ sample. Mass loss was observed around $100^{\circ} \mathrm{C}$ and $850^{\circ} \mathrm{C}$. The first drop was completed within $10 \mathrm{~min}$ and the mass change was just $\sim 1 \mathrm{wt} \%$. The cause for this first drop was presumed to be dehydration of the sample because $\mathrm{Na}_{2} \mathrm{CO}_{3}$ is hygroscopic and can absorb water easily during handling. On the other hand, the second drop was observed at a temperature of $850^{\circ} \mathrm{C}$, completed $10 \mathrm{~min}$ after the temperature reached $900^{\circ} \mathrm{C}$, and the mass change was around $16.1 \mathrm{wt} \%$. The theoretical mass change due to decarbonation of a $\mathrm{Na}_{2} \mathrm{CO}_{3}+\mathrm{Fe}_{2} \mathrm{O}_{3}$ sample is around $16.6 \mathrm{wt} \%$. Therefore, the cause for the second drop in Fig. 3 was considered to be decarbonation of the sample.

Figure 4 shows the XRD pattern obtained from the $\mathrm{Na}_{2} \mathrm{CO}_{3}+\mathrm{Fe}_{2} \mathrm{O}_{3}$ sample after heating at $900^{\circ} \mathrm{C}$ for $30 \mathrm{~min}$. The detected peaks are in good agreement with the literature values for $\alpha-\mathrm{NaFeO}_{2}$, which are represented by square symbols. Consequently, the sample after the heat treatment is believed to contain a single phase of $\alpha-\mathrm{NaFeO}_{2}$. This result

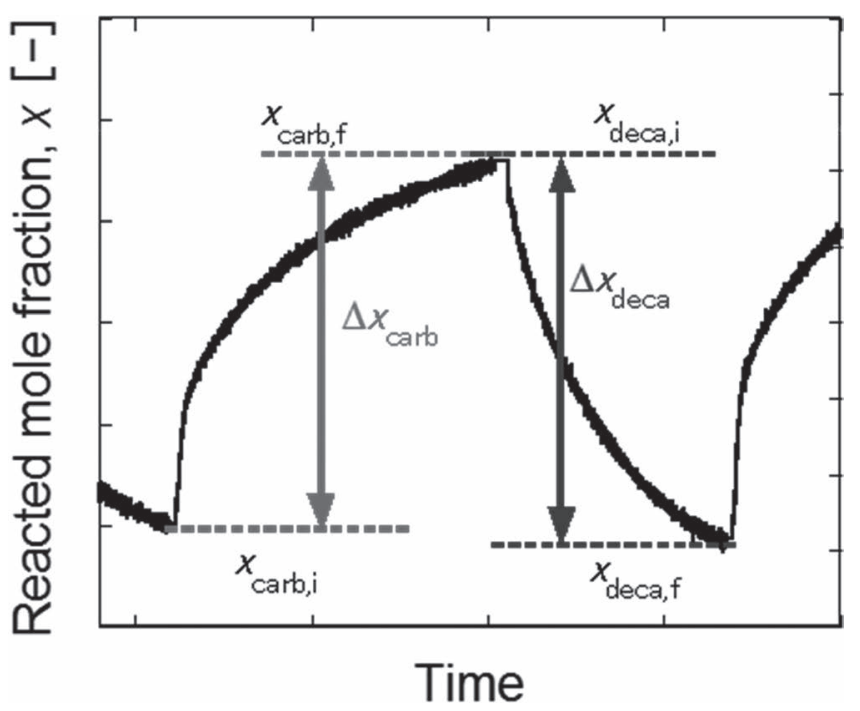

Fig. 2. Definition of changes in reacted mole fraction during carbonation and decarbonation processes. also supports the conclusion that the second drop in Fig. 3 was due to decarbonation of the sample.

Figure 5 shows images of $\mathrm{Na}_{2} \mathrm{CO}_{3}+\mathrm{Fe}_{2} \mathrm{O}_{3}$ and $\mathrm{NaFeO}_{2}$ samples. Both samples were crushed by a mortar and pestle. As shown in Fig. 5(a), the $\mathrm{Na}_{2} \mathrm{CO}_{3}+\mathrm{Fe}_{2} \mathrm{O}_{3}$ sample was brown in color owing to the presence of $\mathrm{Fe}_{2} \mathrm{O}_{3}$. On the other hand, the $\mathrm{NaFeO}_{2}$ sample was olive green as shown in Fig. 5(b). Considering that the $\mathrm{NaFeO}_{2}$ sample contains a single phase of $\alpha-\mathrm{NaFeO}_{2}$, the cause for this color is presumed to be $\alpha-\mathrm{NaFeO}_{2}$.

Figure 6 shows the temperature dependence of $\mathrm{Na}_{2} \mathrm{CO}_{3}+$ $\mathrm{Fe}_{2} \mathrm{O}_{3}$ sample reactivity under $100 \mathrm{kPa}$ of $\mathrm{CO}_{2}$. Decarbonation of the sample was first observed at a temperature around $850^{\circ} \mathrm{C}$, and it proceeded almost completely when the temperature reached $900^{\circ} \mathrm{C}$. At this time, the reacted mole fraction was 0.02 . During the cooling process, carbonation of the sample was observed when the temperature reached about $750^{\circ} \mathrm{C}$. It proceeded until the temperature reached approximately $550^{\circ} \mathrm{C}$, and the reacted mole fraction was $\sim 0.73$. This result confirms that a $\mathrm{NaFeO}_{2}$ sample can react with $\mathrm{CO}_{2}$ around $800^{\circ} \mathrm{C}$ and can therefore potentially be used as TcES material.

In order to investigate the dependence of $\mathrm{Na}_{2} \mathrm{CO}_{3}+\mathrm{Fe}_{2} \mathrm{O}_{3}$

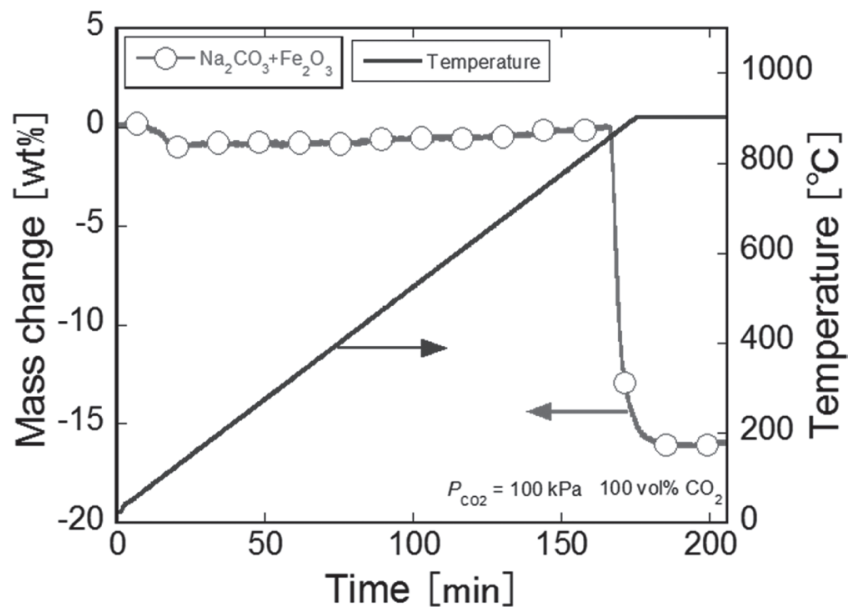

Fig. 3. Thermal decomposition of $\mathrm{Na}_{2} \mathrm{CO}_{3}+\mathrm{Fe}_{2} \mathrm{O}_{3}$ sample.

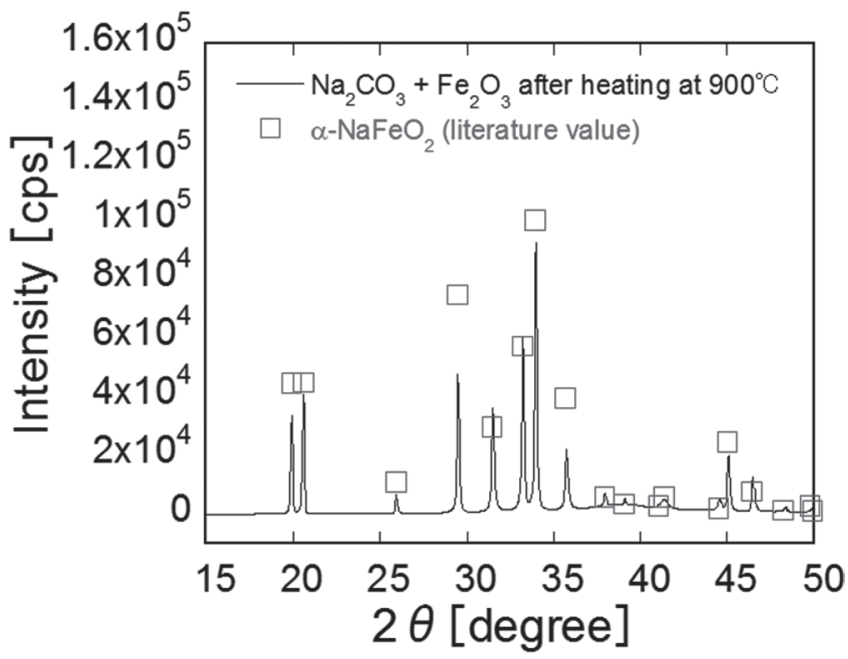

Fig. 4. XRD patterns of $\mathrm{Na}_{2} \mathrm{CO}_{3}+\mathrm{Fe}_{2} \mathrm{O}_{3}$ sample after heating at $900^{\circ} \mathrm{C}$. 
(a)

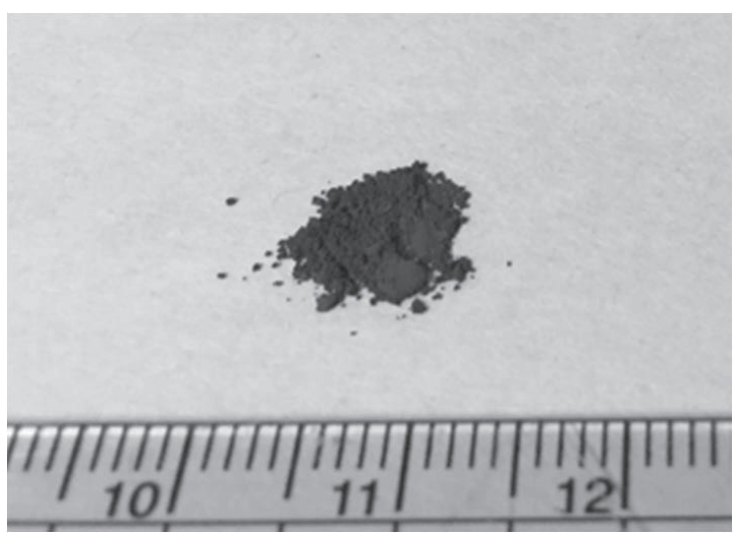

(b)

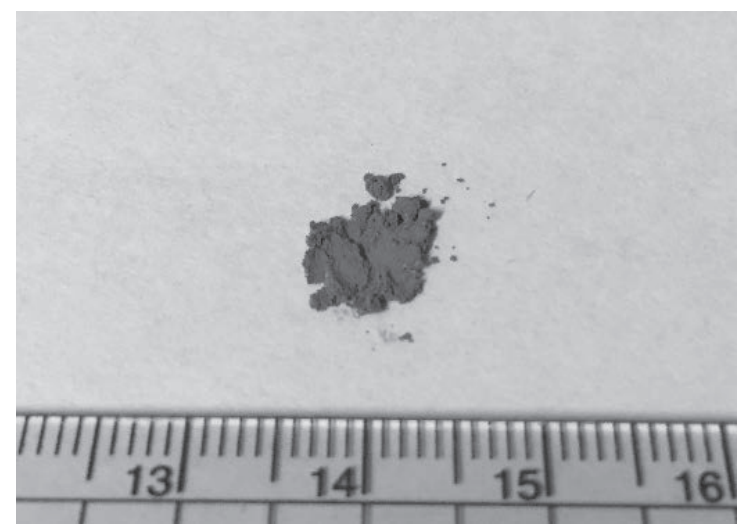

Fig. 5. Images of (a) $\mathrm{Na}_{2} \mathrm{CO}_{3}+\mathrm{Fe}_{2} \mathrm{O}_{3}$ and (b) $\mathrm{NaFeO}_{2}$ powders.

(a)

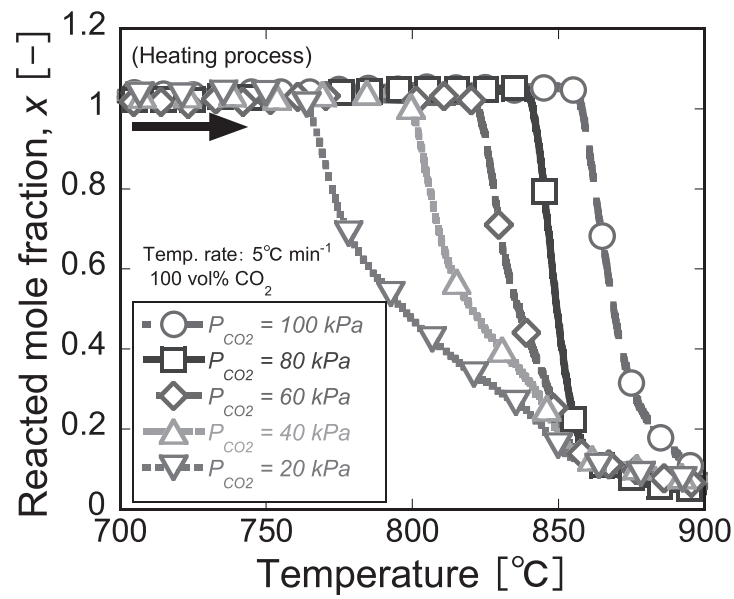

(b)

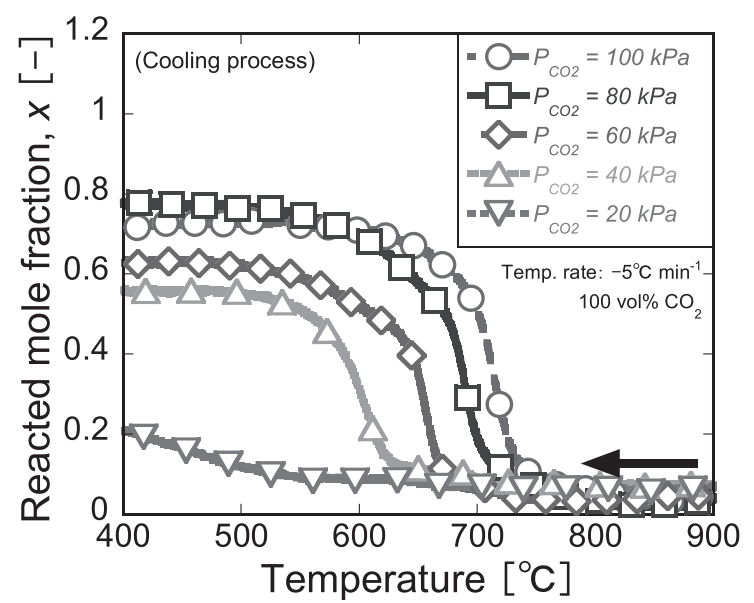

Fig. 7. Pressure dependence of $\mathrm{Na}_{2} \mathrm{CO}_{3}+\mathrm{Fe}_{2} \mathrm{O}_{3}$ reactivity during (a) heating and (b) cooling processes.

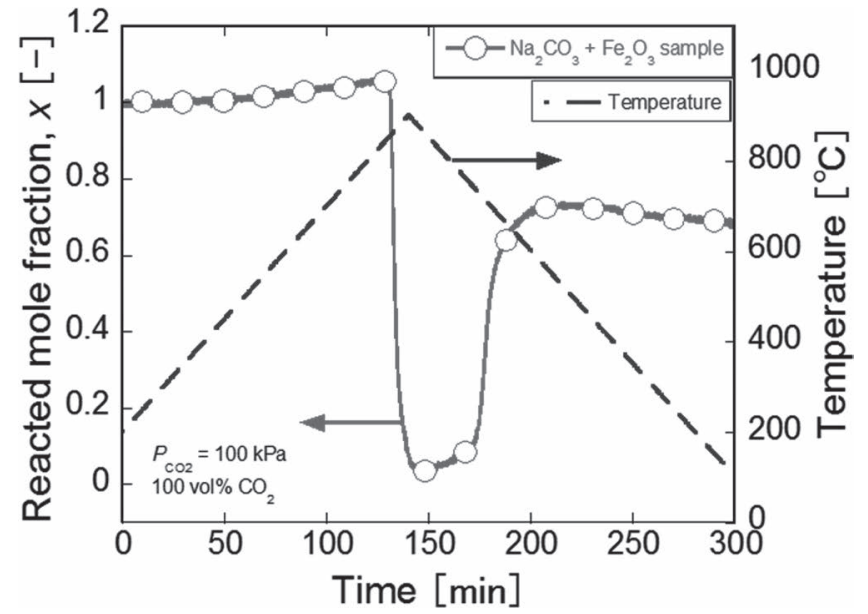

Fig. 6. Temperature dependence of $\mathrm{Na}_{2} \mathrm{CO}_{3}+\mathrm{Fe}_{2} \mathrm{O}_{3}$ reactivity under $100 \mathrm{kPa}$ of $\mathrm{CO}_{2}$ pressure.

reactivity on pressure, the same thermogravimetric experiments were conducted under 5 different $\mathrm{CO}_{2}$ pressures. Results are shown in Fig. 7, where the reacted mole fraction is plotted as the vertical axis and temperature during the heating and cooling processes as the horizontal axis. During the heating process, as shown in Fig. 7(a), decarbonation was observed under all $\mathrm{CO}_{2}$ conditions. The temperatures at which decarbonation began were around 760, 800, 820,
840 , and $860^{\circ} \mathrm{C}$ when the $\mathrm{CO}_{2}$ pressures were $20,40,60,80$, and $100 \mathrm{kPa}$, respectively. Reacted mole fractions reached $4-7 \%$ at $900^{\circ} \mathrm{C}$. Figure $7(\mathrm{~b})$ shows the pressure dependence of sample reactivity during the cooling process. Carbonation was observed under all $\mathrm{CO}_{2}$ conditions, although it proceeded more slowly under a pressure of $20 \mathrm{kPa}$. The temperatures at which carbonation started were around 640 , 680,730 and $750^{\circ} \mathrm{C}$ when the $\mathrm{CO}_{2}$ pressures were 40,60 , 80 , and $100 \mathrm{kPa}$, respectively. The highest reacted mole fraction was 0.78 under $80 \mathrm{kPa}$ at $400^{\circ} \mathrm{C}$. These results confirm that carbonation/decarbonation of $\mathrm{NaFeO}_{2}$ proceeds around $800^{\circ} \mathrm{C}$, and operating conditions can be obtained from Fig. 7.

Figure 8 shows the result of a cyclic experiment using $\mathrm{NaFeO}_{2}$. Carbonation and decarbonation proceeded at $700^{\circ} \mathrm{C}$ for $1 \mathrm{~h}$ and at $900^{\circ} \mathrm{C}$ for $30 \mathrm{~min}$ under $100 \mathrm{kPa}$ of $\mathrm{CO}_{2}$ pressure, respectively. As shown in Fig. 8, $\Delta x_{\text {carb }}$ and $\Delta x_{\text {deca }}$ were 0.714 and 0.743 in the first cycle, respectively. They decreased slightly in the second cycle, and then they continued increasing gradually after the second cycle. Finally, $\Delta x_{\text {carb }}$ and $\Delta x_{\text {deca }}$ reached 0.835 and 0.839 on the 15th cycle, respectively. This result indicates that $\mathrm{NaFeO}_{2}$ has sufficient cyclic durability at high temperatures.

Figure 9 shows $\mathrm{SEM}$ images of $\mathrm{NaFeO}_{2}$ samples before and after carbonation and after 15 cycles under $100 \mathrm{kPa}$ of $\mathrm{CO}_{2}$ pressure. As shown in Figs. 9(a)-9(c), small particles (around $1 \mu \mathrm{m}$ ) of $\mathrm{NaFeO}_{2}$ are mutually connected to each 
other and form aggregates. After carbonation, the small particles have almost disappeared, and the spaces between particles have clearly decreased in Figs. 9(d)-9(f). This seems to have occurred due to carbonation and sintering at high temperature, and this seemingly caused the decrease in reactivity during the 2nd cycle in Fig. 8. On the other hand, the porous structure of the sample appeared after the

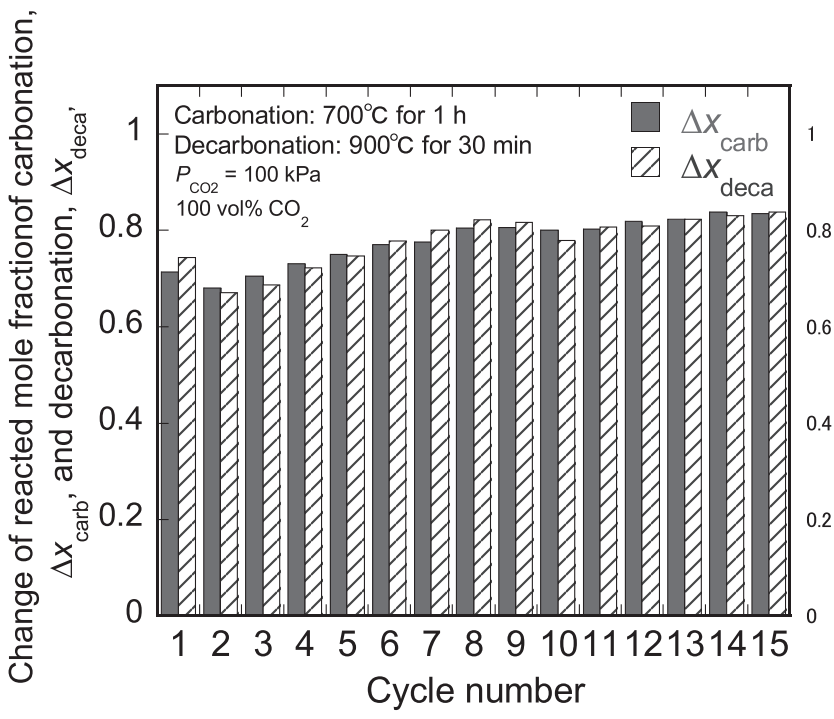

Fig. 8. Cyclic durability of $\mathrm{NaFeO}_{2}$ reactivity under $100 \mathrm{kPa}$ by TS method. Carbonation process: $700^{\circ} \mathrm{C}$ for $1 \mathrm{~h}$. Decarbonation process: $900^{\circ} \mathrm{C}$ for $30 \mathrm{~min}$.

(a)

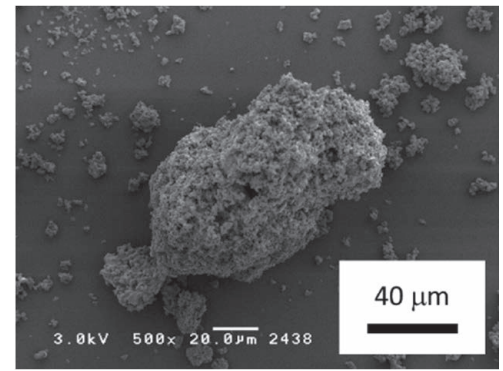

(d)

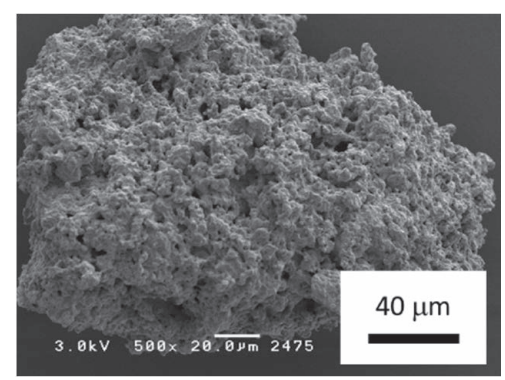

(g)

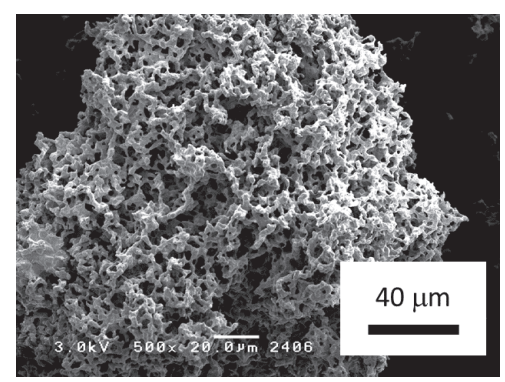

(b)

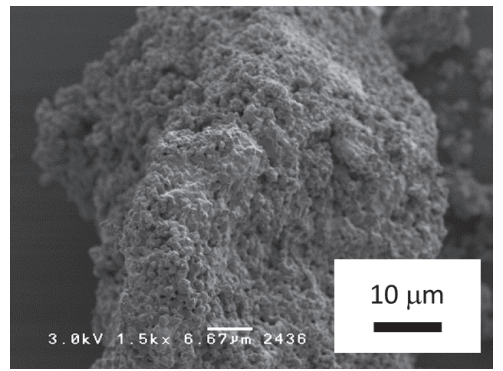

(e)

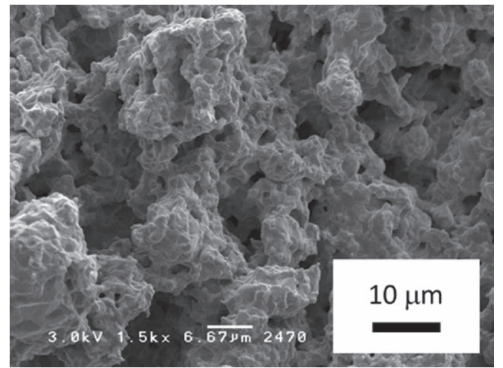

(h)

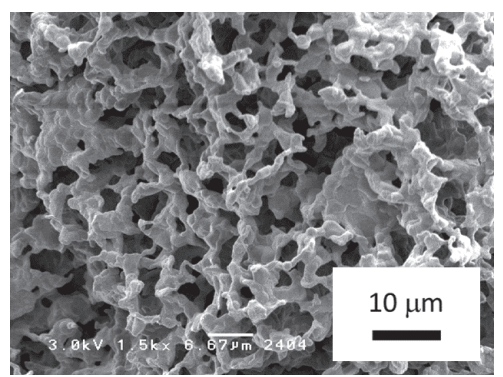

(c)

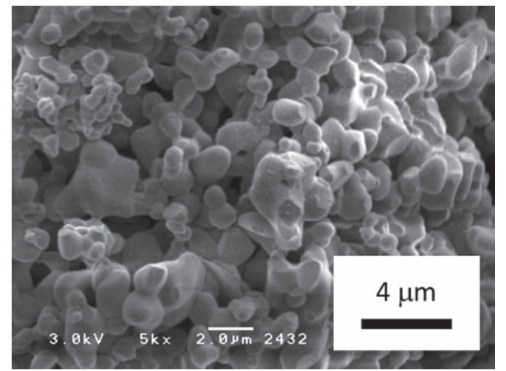

(f)

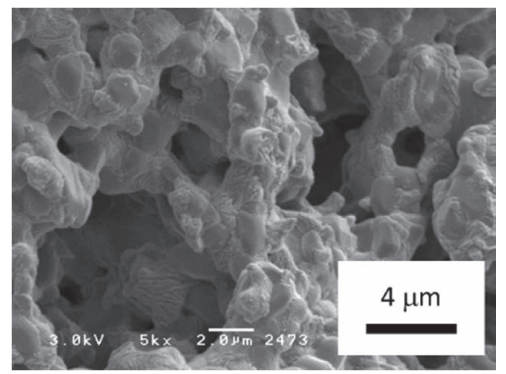

(i)

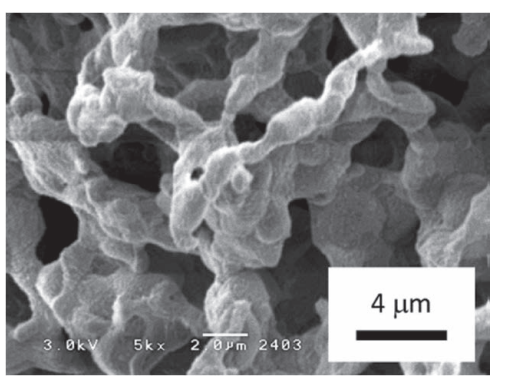

Fig. 9. SEM images of (a-c) $\mathrm{NaFeO}_{2}$, sample (d-f) after carbonation, and (g-i) after 15 cycle under $100 \mathrm{kPa}$ as $\mathrm{CO}_{2}$ pressure. 


\section{Conclusion}

Thermogravimetric experiments were conducted with the aim of investigating the reaction between $\mathrm{NaFeO}_{2}$ and $\mathrm{CO}_{2}$. XRD analysis confirmed that $\mathrm{Na}_{2} \mathrm{CO}_{3}+\mathrm{Fe}_{2} \mathrm{O}_{3}$ samples were converted into $\mathrm{NaFeO}_{2}$ after heating at $900^{\circ} \mathrm{C}$. Decarbonation and carbonation reactions proceeded at temperatures above $850^{\circ} \mathrm{C}$ and below $750^{\circ} \mathrm{C}$ under $100 \mathrm{kPa}$ of $\mathrm{CO}_{2}$ pressure, respectively. The starting temperatures for decarbonation and carbonation decreased with decreasing $\mathrm{CO}_{2}$ pressure. A cyclic experiment was conducted using a pressure swing absorption method at $700-900^{\circ} \mathrm{C}$. The change in the reacted mole fraction kept increasing overall after the second cycle, and it reached 0.835 during the 15 th cycle. From the results of SEM imaging, a porous structure was formed after the 15 th cycle. This improved $\mathrm{CO}_{2}$ diffusivity appears to be the cause of enhanced reactivity with increasing cycle number during the cyclic experiment. The volumetric and the gravimetric thermal energy densities of $\mathrm{NaFeO}_{2}$ were estimated as $760 \mathrm{~kJ} \mathrm{~L}^{-1}$ and $450 \mathrm{~kJ} \mathrm{~kg}^{-1}$. These results indicate that $\mathrm{NaFeO}_{2}$ has the potential to be used as a TcES material around $700-900^{\circ} \mathrm{C}$ for utilization of surplus heat in iron-making and other high-temperature processes.

\section{Acknowledgement}

This work was supported by Council for Science, Technology and Innovation (CSTI), Cross-ministerial Strategic Innovation Promotion Program (SIP), Energy Carriers (Funding agency: JST).

\section{REFERENCES}

1) BP Statistical Review of World Energy 2017, BP plc, London, (2017), 10.

2) Japan's Energy White Paper 2016, Research Institute of Economy, Trade and Industry,Agency for Natural Resources and Energy: Tokyo, (2016), 141.

3) International Energy Outlook 2016, U. S. Energy Information Administration: International Energy Agency, Paris, (2016), 118.

4) G. Y. Ma, J. J. Cai, W. W. Zeng and H. Dong: Energy Procedia, 14 (2012), 1022.

5) N. Maruoka, K. Sato, J.-I. Yagi and T. Akiyama: ISIJ Int., 42 (2002), 215.

6) N. Maruoka, T. Mizuochi, H. Purwanto and T. Akiyama: ISIJ Int., 44 (2004), 257.

7) N. Shigaki, H. Tobo, S. Ozawa, Y. Ta and K. Hagiwara: ISIJ Int., 55 (2015), 2258.

8) H. Zhang, H. Wang, X. Zhu, Y. J. Qiu, K. Li, R. Chen and Q. Liao: Appl. Energy, 112 (2013), 956.

9) M. Sakakibara: Tetsu-to-Hagané, 76 (1990), 1587 (in Japanese).

10) T. Steinparzer, M. Haider, A. Fleischanderl, A. Hampel, G. Enickl and F. Zauner: J. Phys. Conf. Ser., 395 (2012), 012158.

11) O. Myagmarjav, J. Ryu and Y. Kato: ISIJ Int., 55 (2015), 464.

12) Y. Kato, N. Harada and Y. Yoshizawa: Appl. Therm. Eng., 19 (1999), 239.

13) Y. Kato, T. O-shima and Y. Yoshizawa: Int. J. Energy Res., 25 (2001), 577.

14) Y. Kato, M. Yamada, T. Kanie and Y. Yoshizawa: Nucl. Eng. Des., 210 (2001), 1.

15) H. Takasu and Y. Kato: Energy Procedia, 131 (2017), 94.

16) H. Takasu, J. Ryu and Y. Kato: Appl. Energy, 193 (2017), 74.

17) M. Kato and K. Nakagawa: J. Ceram. Soc. Jpn., 109 (2001), 911.

18) K. Nakagawa and T. Ohashi: J. Electrochem. Soc., 145 (1998), 1344.

19) Outotec: HSC Chemistry ver. 7.0, Outotec, Pori, Software available at www.outotec.com/HSC, (accessed 2018-11-01).

20) I. Barin: Thermochemical Data of Pure Substances, 3rd ed., VCH Publishers, Inc., New York, (1995), 985.

21) Mineral Commodity Summaries 2017, U.S. Department of the Interior: The U. S. Government Publishing Office, Washington, DC, (2017), 92.

22) I. Yanase, S. Onozawa, K. Ogasawara and H. Kobayashi: $\mathrm{J} \mathrm{CO}_{2}$ Util., 24 (2018), 200.

23) H. Kaneko, Y. Hosokawa, N. Kojima, N. Gokon, N. Hasegawa, M. Kitamura and Y. Tamaura: Energy, 26 (2001), 919. 